\title{
Zinc as a multipurpose trace element
}

\author{
R. Marchan $\cdot$ C. Cadenas $\cdot$ H. M. Bolt
}

Published online: 14 March 2012

(C) Springer-Verlag 2012

Zinc is an essential element with growing relevance in the fields of human health and disease. Therefore, the editors welcome the contribution of Maria Stefanidou and colleagues from the University of Athens on zinc and its influence on human health (Chasapis et al. 2011; this issue). The comprehensive review provides an update on the role of zinc:

- In transcription control mediated by the aptly named zinc finger transcription factors whose stability is mediated by zinc

- In proliferation, because zinc is required for the activity of enzymes involved in DNA synthesis, e.g., deoxythymidine kinase

- In oxidative stress control, because high levels of reactive oxygen species cause a release of zinc from metallothionein

- In immune response, primarily because zinc deficiency reduces the killing capacity of natural killer cells.

- In the pathogenesis of numerous diseases, including cardiovascular diseases, cancer, Alzheimer's disease, diabetes mellitus, Wilson's disease and depression.

A special focus of the review of Chasapis et al. (2011; this issue) is the role of zinc in apoptosis, which is particularly welcome, since the control mechanisms of apoptosis is critical for the fields of toxicology and cancer research (Lee et al. 2010, 2011; Kirsch-Volders et al. 2011; Yen et al. 2011; Wang et al. 2011; Fang et al. 2011; Cheng et al. 2011; Golka et al. 2011; Kunwar et al. 2011; Baird and Dinkova-

R. Marchan $(\varangle) \cdot$ C. Cadenas $\cdot$ H. M. Bolt Leibniz Institut für Arbeitsforschung an der TU Dortmund, Leibniz Research Centre for Working Environment and Human Factors (IfADo), Ardeystrasse 67, 44139 Dortmund, Germany e-mail: marchan@ifado.de
Kostova 2011; Sun et al. 2011; Stewart et al. 2011; Zhao et al. 2011; Park et al. 2011; El Hakim et al. 2011; Ilowski et al. 2011; Godoy et al. 2009, 2010; Petry et al. 2010; Franke et al. 2009; Hardelauf et al. 2011; Cadenas et al. 2010). Zinc is a known inhibitor of apoptosis. One mechanism by which zinc influences apoptosis is through the modulation of P53 binding to DNA, occurring at physiological intracellular zinc concentrations. A second relevant mechanism is the inhibition of caspases by zinc. The present article by Maria Stefanidou gives a comprehensive summary of recent research and is highly recommended for all interested in the various biological processes controlled by this multipurpose essential element.

\section{References}

Baird L, Dinkova-Kostova AT (2011) The cytoprotective role of the Keap1-Nrf2 pathway. Arch Toxicol 85:241-272 (Review)

Cadenas C, Franckenstein D, Schmidt M, Gehrmann M, Hermes M, Geppert B, Schormann W, Maccoux LJ, Schug M, Schumann A, Wilhelm C, Freis E, Ickstadt K, Rahnenführer J, Baumbach JI, Sickmann A, Hengstler JG (2010) Role of thioredoxin reductase 1 and thioredoxin interacting protein in prognosis of breast cancer. Breast Cancer Res 12:R44

Chasapis CT, Loutsidou AC, Spiliopoulou CA, Stefanidou ME (2011) Zinc and human health: an update. Arch Toxicol. doi:10.1007/ s00204-011-0775-1

Cheng JS, Shu SS, Kuo CC, Chou CT, Tsai WL, Fang YC, Kuo LN, Yeh JH, Chen WC, Chien JM, Lu T, Pan CC, Cheng HH, Chai KL, Jan CR (2011) Effect of diindolylmethane on $\mathrm{Ca}(2+)$ movement and viability in HA59T human hepatoma cells. Arch Toxicol 85:1257-1266

El Hakim AE, Gamal-Eldeen AM, Shahein YE, Mansour NM, Wahby AF, Abouelella AM (2011) Purification and characterization of a cytotoxic neurotoxin-like protein from Naja haje haje venom that induces mitochondrial apoptosis pathway. Arch Toxicol 85: 941-952 
Fang EF, Pan WL, Wong JH, Chan YS, Ye XJ, Ng TB (2011) A new Phaseolus vulgaris lectin induces selective toxicity on human liver carcinoma Hep G2 cells. Arch Toxicol 85:1551-1563

Franke H, Sauer C, Rudolph C, Krügel U, Hengstler JG, Illes P (2009) $\mathrm{P} 2$ receptor-mediated stimulation of the PI3-K/Akt-pathway in vivo. Glia 57:1031-1045

Godoy P, Hengstler JG, Ilkavets I, Meyer C, Bachmann A, Müller A, Tuschl G, Mueller SO, Dooley S (2009) Extracellular matrix modulates sensitivity of hepatocytes to fibroblastoid dedifferentiation and transforming growth factor beta-induced apoptosis. Hepatology 49:2031-2043

Godoy P, Schug M, Bauer A, Hengstler JG (2010) Reversible manipulation of apoptosis sensitivity in cultured hepatocytes by matrix-mediated manipulation of signaling activities. Methods Mol Biol 640:139-155

Golka K, Selinski S, Lehmann ML, Blaszkewicz M, Marchan R, Ickstadt K, Schwender H, Bolt HM, Hengstler JG (2011) Genetic variants in urinary bladder cancer: collective power of the "wimp SNPs". Arch Toxicol 85:539-554 (Review)

Hardelauf H, Frimat JP, Stewart JD, Schormann W, Chiang YY, Lampen P, Franzke J, Hengstler JG, Cadenas C, Kunz-Schughart LA, West J (2011) Microarrays for the scalable production of metabolically relevant tumour spheroids: a tool for modulating chemosensitivity traits. Lab Chip 11:419-428

Ilowski M, Kleespies A, de Toni EN, Donabauer B, Jauch KW, Hengstler JG, Thasler WE (2011) Augmenter of liver regeneration (ALR) protects human hepatocytes against apoptosis. Biochem Biophys Res Commun 404:148-152

Kirsch-Volders M, Plas G, Elhajouji A, Lukamowicz M, Gonzalez L, Vande Loock K, Decordier I (2011) The in vitro MN assay in 2011: origin and fate, biological significance, protocols, high throughput methodologies and toxicological relevance. Arch Toxicol 85:873-899 (Review)

Kunwar A, Bag PP, Chattopadhyay S, Jain VK, Priyadarsini KI (2011) Anti-apoptotic, anti-inflammatory, and immunomodulatory activities of 3,3'-diselenodipropionic acid in mice exposed to whole body $\gamma$-radiation. Arch Toxicol 85:1395-1405 Erratum in: Arch Toxicol 85:1641-3

Lee JH, Jung C, Javadian-Elyaderani P, Schweyer S, Schütte D, Shoukier M, Karimi-Busheri F, Weinfeld M, Rasouli-Nia A,
Hengstler JG, Mantilla A, Soleimanpour-Lichaei HR, Engel W, Robson CN, Nayernia K (2010) Pathways of proliferation and antiapoptosis driven in breast cancer stem cells by stem cell protein piwil2. Cancer Res 70:4569-4579

Lee YS, Kim DW, Lee YH, Oh JH, Yoon S, Choi MS, Lee SK, Kim JW, Lee K, Song CW (2011) A Silver nanoparticles induce apoptosis and $\mathrm{G} 2 / \mathrm{M}$ arrest via $\mathrm{PKC} \zeta$-dependent signaling in A549 lung cells. Arch Toxicol 85:1529-1540

Park JY, Kim MJ, Kim YK, Woo JS (2011) Ceramide induces apoptosis via caspase-dependent and caspase-independent pathways in mesenchymal stem cells derived from human adipose tissue. Arch Toxicol 85:1057-1065

Petry IB, Fieber E, Schmidt M, Gehrmann M, Gebhard S, Hermes M, Schormann W, Selinski S, Freis E, Schwender H, Brulport M, Ickstadt K, Rahnenführer J, Maccoux L, West J, Kölbl H, Schuler M, Hengstler JG (2010) ERBB2 induces an antiapoptotic expression pattern of Bcl-2 family members in node-negative breast cancer. Clin Cancer Res 16:451-460

Stewart JD, Hengstler JG, Bolt HM (2011) Contrast agent-induced nephrotoxicity: role of oxidative stress and apoptosis through the mitochondrial pathway. Arch Toxicol 85:163-164

Sun Z, Niu R, Wang B, Jiao Z, Wang J, Zhang J, Wang S, Wang J (2011) Fluoride-induced apoptosis and gene expression profiling in mice sperm in vivo. Arch Toxicol 85:1441-1452

Wang Z, Yang X, Yang S, Ren G, Ferreri M, Su Y, Chen L, Han B (2011) Sodium fluoride suppress proliferation and induce apoptosis through decreased insulin-like growth factor-I expression and oxidative stress in primary cultured mouse osteoblasts. Arch Toxicol 85:1407-1417

Yen CC, Ho TJ, Wu CC, Chang CF, Su CC, Chen YW, Jinn TR, Lu TH, Cheng PW, Su YC, Liu SH, Huang CF (2011) Inorganic arsenic causes cell apoptosis in mouse cerebrum through an oxidative stress-regulated signaling pathway. Arch Toxicol 85: 565-575

Zhao XF, Wang Q, Ji YL, Wang H, Liu P, Zhang C, Zhang Y, Xu DX (2011) Fenvalerate induces germ cell apoptosis in mouse testes through the Fas/FasL signaling pathway. Arch Toxicol 85: 1101-1108 